\title{
B Lymphoblastic Leukemia/Lymphoma with Recurrent Genetic Abnormalities
}

National Cancer Institute

\section{Source}

National Cancer Institute. B Lymphoblastic Leukemia/Lymphoma with Recurrent Genetic Abnormalities. NCl Thesaurus. Code C80328.

The term refers to precursor lymphoid neoplasms which are composed of Blymphoblasts and characterized by the presence of recurrent genetic abnormalities. 